
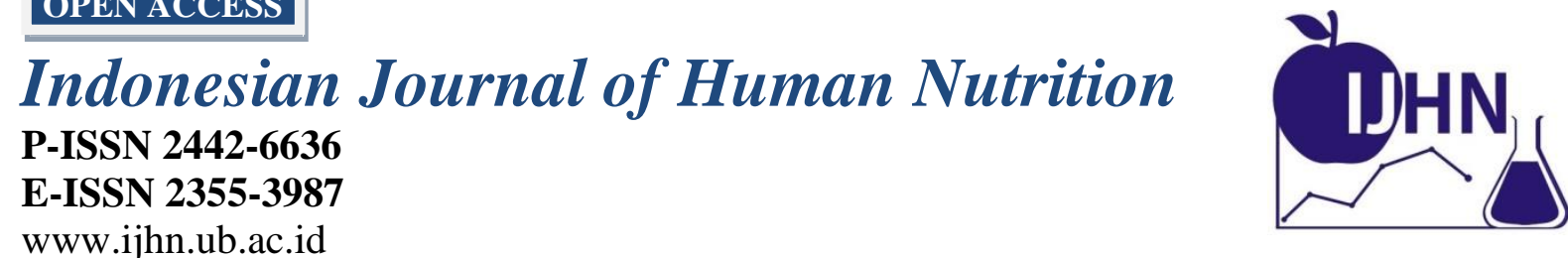

Artikel Hasil Penelitian

\title{
Daya Simpan Susu Kacang Hijau (Phaseolus radiatus L.) dengan Persentase Penambahan Sari Jahe Merah (Zingiber officinale var. Rubrum)
}

\section{(Storability Capacity of Mung Bean Milk (Phaseolus radiatus L.) with The Added Percentage of Red Ginger Extract (Zingiber officinale var. Rubrum))}

\author{
Meilla Dwi Andrestian ${ }^{1} *$ dan Husnul Hatimah ${ }^{1}$ \\ ${ }^{1}$ Jurusan Gizi Politeknik Kesehatan Kemenkes Banjarmasin \\ * Alamat korespondensi, E-mail : meilladwi74@gmail.com, Telp/Fax :(0511) \\ 4368621/ (0511) 4772288
}

Diterima: / Direview: / Dimuat: Februari 2015 / Maret 2015 / Juni 2015

\begin{abstract}
Abstrak
Susu kacang hijau adalah salah satu diversifikasi pangan hasil olahan kacang hijau. Proses pembuatan susu kacang hijau dengan menggunakan teknik Ultra High Temperature (UHT) banyak dijual di pasaran. Sebagai alternatif lain agar susu kacang hijau memiliki daya simpan yang tinggi tanpa memerlukan peralatan dan biaya yang besar, maka perlu adanya penambahan bahan pengawet alami seperti jahe merah pada produk susu kacang hijau. Secara umum penelitian ini bertujuan untuk mengetahui pengaruh persentase penambahan sari jahe merah (Zingiber officinale var. Rubrum) terhadap daya simpan susu kacang hijau (Phaseolus radiatus L.). Penelitian ini terdiri dari dua tahap yaitu penelitian pendahuluan dan penelitian utama. Penelitian pendahuluan dilakukan untuk mengetahui daya terima (organoleptik) yang terbaik dari beberapa variasi sembilan perlakuan penambahan sari jahe merah. Setelah penelitian pendahuluan dilakukan dan diperoleh hasil perlakuan terbaik yang disukai panelis, dilanjutkan dengan penelitian utama untuk mengetahui daya simpan susu kacang hijau. Hasil dari penelitian pendahuluan didapat tiga perlakuan yang disukai panelis yaitu P3 $(0,75 \%)$, P5 $(1,25 \%)$, dan P6 (1,5\%). Tiga perlakuan tersebut kemudian diujikan daya simpannya pada penelitian utama. Didapatkan hasil bahwa Q0 (perlakuan kontrol) dapat bertahan selama 0 hari, perlakuan Q1 dengan penambahan sari jahe merah $0,75 \%$ dan Q2 $(1,25 \%)$ memiliki daya simpan selama 1 hari, dan Q3 (1,5\%) merupakan perlakuan yang terbaik yang memiliki daya simpan terlama yaitu selama 2 hari. Semakin banyak penambahan sari jahe merah, maka semakin lama daya simpan susu kacang hijau. Susu kacang hijau terbaik yang disukai dan memiliki daya simpan yang lama adalah dengan penambahan sari jahe merah sebanyak $1,5 \%$.
\end{abstract}

Kata kunci : susu kacang hijau, daya simpan, jahe merah

\section{Abstract}

Mung bean milk is one of the diversification of processed mung beans. The process of making mung bean milk using Ultra High Temperature (UHT) is abundantly sold in the market. As another alternative to have a high shelf life, it needs the addition of natural preservatives 
such as red ginger. In general, this research aim was to determine the effect of addition of the percentage of red ginger extract (Zingiber officinale var. Rubrum) on storability of green beans milk (Phaseolus radiatus L.). This research consisted of two phases, preliminary research and main research. The former stage was conducted to determine the best acceptability of nine treatment variations of red ginger extract addition. After preliminary research was made and it obtained the best results preferred by panelist, it was then followed by main research to determine the storability of green beans milk. From preliminary research, theres were three treatment preferred by panelists, namely P3 (0.75\%), P5 (1.25\%) and P6 (1.5\%). After that, those treatments were tested for their storability in main research. From main research it showed that $Q O$ (control treatment) can last for $O$ day, $Q 1$ treatment with the addition of red ginger extract $0,75 \%$ and $Q 2(1.25 \%)$ having storability for 1 day and $Q 3(1.5 \%)$ having the best treatment that had the longest storability (for 2 days). The more addition of red ginger extract, the longer storability of green beans milk. The best favored and longest storability of green beans milk was one added with red ginger extract of $1.5 \%$.

Keywords: Green Bean Milk, Storability, Red ginger

\section{PENDAHULUAN}

Salah satu sumber alternatif protein yang baik yang dapat mengurangi prevalensi kekurangan protein di Indonesia adalah kacangkacangan. Kacang-kacangan (leguminosa) merupakan protein nabati yang harganya lebih murah dan terjangkau jika dibandingkan sumber protein hewani seperti daging, unggas, telur ataupun susu. Di antara kacang-kacangan tersebut, kacang hijau merupakan salah satu kacang-kacangan yang cukup penting karena kacang hijau merupakan kacang-kacangan yang digemari dan sering dikonsumsi di masyarakat. Kacang hijau diketahui mengandung protein sebanyak 20-25 persen dan pada kacang hijau mentah memiliki daya cerna sekitar 77 persen serta banyak dimanfaatkan menjadi bahan baku pangan, pakan ternak, dan kosmetik [1,2].

Produksi kacang hijau di Kalimantan Selatan pada tahun 2011 sekitar 774 ton dan pada tahun 2012 mengalami peningkatan menjadi 843 ton [3]. Tingginya produksi kacang hijau tersebut perlu diimbangi dengan penganekaragaman atau diversifikasi produk olahannya agar para petani termotivasi untuk tetap memproduksi kacang hijau dan terus meningkatkan produksinya karena semakin tingginya permintaan pasar. Penganekaragaman produk olahan kacang hijau bertujuan untuk memberikan alternatif pilihan produk pada konsumen.

Diversifikasi produk olahan pangan berbahan baku atau bahan dasar kacang hijau sampai saat ini masih relatif terbatas, hanya dikonsumsi sebagai kecambah kacang hijau (tauge) dan olahan kue tradisional seperti kue untuk-untuk, onde-onde dan bubur kacang hijau. Bubur kacang hijau merupakan salah satu olahan kacang hijau yang paling sering dikonsumsi di Kalimantan Selatan. Tidak hanya di daerah ini, bahkan hampir di seluruh Indonesia bubur kacang hijau banyak disukai dikarenakan bubur kacang hijau merupakan makanan tradisional yang padat gizi dan sebagai salah satu bentuk Program Makanan Tambahan (PMT) untuk anak balita pada penyelenggaraan posyandu [4]. Berdasarkan data statistik menunjukkan bahwa konsumsi bubur kacang hijau selama setahun pada tahun 2007 adalah 3,233 porsi/kapita/tahun dan pada tahun 2008 meningkat menjadi 3,441 porsi/kapita/tahun [5]. Inilah yang menginspirasi industri pangan untuk memproduksi minuman susu kacang hijau.

Susu kacang hijau adalah salah satu usaha diversifikasi pangan hasil olahan kacang hijau. Minuman ini mulai cukup dikenal di masyarakat sebagai minuman kesehatan. Meskipun popularitas susu kacang hijau memang masih kalah jika dibandingkan dengan susu kedelai. Namun kandungan gizi kacang hijau tidak jauh berbeda dengan kedelai. Seperti halnya susu kedelai, susu kacang hijau merupakan susu nabati yang dapat dikonsumsi oleh penderita lactose intolerance (intoleransi laktosa) atau oleh orang yang alergi terhadap susu sapi [1]. Minuman susu 
kacang hijau juga sangat baik dikonsumsi oleh berbagai kalangan usia, khususnya untuk golongan rawan seperti bayi, anak-anak, ibu hamil, dan ibu menyusui [4].

Saat ini di pasaran sudah dijumpai susu kacang hijau yang dalam proses pembuatannya menggunakan teknik pemanasan Ultra High Temperature (UHT). Teknik UHT adalah pemanasan dalam suhu tinggi dengan waktu yang hanya beberapa detik. Proses pengolahan UHT yang kemudian diikuti pengemasan secara aseptik akan melindungi minuman kacang hijau dari kerusakan gizi dan kontaminasi bakteri pembusuk [4]. Namun, pada pengolahan susu kacang hijau yang diproduksi oleh industri kecil atau home industry dan industri menengah akan kesulitan menggunakan teknologi UHT karena kendala biaya dan peralatan, sehingga akan menurunkan kualitas susu kacang hijau yang diproduksi akibat kerusakan oleh mikroba yang memperpendek umur simpan susu kacang hijau. Oleh karena itu, agar susu kacang hijau memiliki daya simpan yang tinggi tanpa memerlukan peralatan dan biaya yang besar, perlu adanya penambahan bahan pengawet alami pada produk susu kacang hijau, misalnya rempah jahe.

Jahe yang merupakan salah satu rempahrempah yang memiliki kemampuan mempertahankan kualitas pangan yaitu sebagai antimikroba. Gingerone dan gingerol berperan dalam menghambat pertumbuhan bakteri Escheria coli dan Bacillus subtilis [6]. Nurcahyo menyebutkan bahwa aktivitas antimikroba jahe yang sangat peka menghambat pertumbuhan Salmonella thypii (bakteri gram negatif penyebab tipus), Bacillus cereus, dan Staphilococcus aureus (bakteri gram positif penyebab gangguan pencernaan) [7]. Berdasarkan hasil penelitian Ernawati, diketahui bahwa sari rimpang jahe memiliki efek antibakteri terhadap jumlah bakteri E. coli pada susu pasteurisasi [8].

Jahe juga memiliki manfaat sebagai obat herbal untuk beberapa penyakit diantaranya sebagai antimuntah (antiematic), antibatuk (antitussive/expectorant), merangsang pengeluaran keringat, dan menghangatkan tubuh [9]. Menurut Rukmana, jahe juga dapat menghilangkan masuk angin, mengurangi atau mencegah influenza, rematik dan batuk serta mengurangi rasa sakit (analgesik) dan bengkak (antiinflamasi) [10]. Kegunaannya lainnya adalah untuk mengobati penyakit asma, stroke, sakit gigi, diabetes, sakit otot, tenggorokan, kram, hipertensi, demam, dan infeksi [11-13]. Selain itu, mengkonsumsi jahe dapat merangsang pengeluaran air liur dan memperlancar cairan pencernaan [14].

Dalam industri skala besar susu kacang hijau, jahe ditambahkan hanya bertujuan untuk menambah cita rasa (flavor). Sama seperti pada pengolahan bubur kacang hijau, biasanya diberikan penambahan jahe sebagai penyedap rasa dan aroma yang dapat menghilangkan bau langu pada kacang-kacangan.

Oleh karena jahe memiliki berbagai manfaat khususnya sebagai antimikroba, maka perlu dilakukan penelitian mengenai pengaruh penambahan jahe sebagai zat antimikroba yang dapat memperpanjang daya simpan susu kacang hijau. Dalam penelitian ini digunakan jahe merah karena dibandingkan jahe emprit (jahe putih kecil) atau jahe gajah (jahe putih besar), jahe merah banyak dikenal dan dibudidayakan di Kalimantan Selatan, sehingga konsumsi jahe merah lebih sering dibandingkan jahe lainnya. Menurut Lentera, dari ketiga jenis jahe yang ada, jahe merah lebih banyak memiliki khasiat sebagai obat karena kandungan minyak atsiri dan oleoresinnya paling tinggi dibandingkan dengan jenis jahe yang lain [15]. Selain itu, kandungan gingerol jahe merah lebih tinggi dibanding jahe lainnya [5], sehingga jahe merah lebih efektif dalam memperpanjang daya simpan susu kacang hijau. Berdasarkan penjelasan di atas, maka perlu dilakukan penelitian mengenai pengaruh persentase penambahan sari jahe merah (Zingiber officinale var. Rubrum) terhadap daya simpan susu kacang hijau (Phaseolus radiatus L.). Selain itu, perlu juga dilakukan penelitian untuk mengetahui persentase penambahan sari jahe merah yang disukai dan memiliki daya simpan yang cukup lama. Oleh karena itu, perlu dilakukan penelitian mengenai pengaruh persentase penambahan sari jahe merah (Zingiber officinale var. Rubrum) terhadap daya simpan susu kacang hijau (Phaseolus radiatus L.).

Penelitian ini merupakan penelitian berbasis teknologi pangan yang bertujuan untuk mengembangkan produk olahan kacang hijau sebagai upaya diversifikasi pangan yaitu dengan mengolah susu nabati yang kaya akan protein sebagai pengganti susu hewani. Selain itu, penelitian ini juga dimaksudkan untuk mengolah produk pangan fungsional yang berguna untuk 
kesehatan dengan penambahan sari jahe merah sebagai penambah kualitas susu kacang hijau.

Proses pembuatan susu kacang hijau hampir sama dengan pembuatan susu kacang-kacangan lain [16]. Hanya saja ekstraksi kacang hijau tidak memerlukan perlakuan khusus seperti pada pembuatan susu kedelai untuk mengurangi bau langu karena rendahnya senyawa antigizi $[17,18]$. Kacang hijau mengandung kadar antigizi yang tidak berarti sehingga tidak diperlukan perlakuan khusus pada saat pengolahan [18]. Kadar asam fitat kacang hijau adalah $12,0 \mathrm{mg} / \mathrm{g}$, lebih rendah dari kedelai yaitu 36,4 mg/g [18]. Persyaratan mutu susu kacang hijau belum ada, oleh karena itu persyaratan mutu susu kacang hijau mengacu pada persyaratan mutu SNI susu kedelai dengan SNI 01-3830-1995 [19].

Susu kacang hijau ditambahkan sari jahe merah karena jahe memiliki efek yang bervariasi jika digunakan dalam makanan tidak hanya pada flavor, kepedasan, dan karakter warna tetapi juga berfungsi sebagai antioksidan, antimikroba, dan obat [20]. Rasa jahe yang pedas disebabkan oleh komponen bioaktif kandungan minyak atsiri. Komponen bioaktif tersebut diketahui dapat berfungsi sebagai pengawet yang tidak toksik yang dapat menghambat pertumbuhan dan membunuh mikroba [20].

Aktivitas antimikroba jahe terhadap mikroba perusak dan patogen menunjukkan memiliki kemampuan mengawetkan, sehingga tidak perlu lagi menambahkan bahan pengawet dan mencegah kerusakan makanan. Zat-zat antimikroba dapat bersifat bakteriostatik (menghambat perkembangan pertumbuhan bakteri), bakterisidal (membunuh bakteri), fungisidal (membunuh kapang), fungistatik (mencegah pertumbuhan kapang) ataupun germisidal (menghambat germinasi spora bakteri) [21]. Hal ini terlihat dari aktivitas antimikrobanya yang sangat peka menghambat pertumbuhan Salmonella thypii (bakteri gram negatif penyebab tipus), Bacillus cereus, Lactobacillus acidophilus dan Staphylococcus aureus. Jahe juga dapat menghambat pertumbuhan Aspergillus, yang merupakan jamur yang dapat memproduksi aflatoksin. Selain itu, jahe juga dapat menghambat Saccharomyces cereviceae dan Mycoderma spp [22]. Antimikroba merupakan senyawa yang mampu menghambat, bahkan membunuh mikrobia dalam konsentrasi tertentu [20].
Jahe seperti halnya jenis rempah-rempah yang lain juga memiliki kemampuan mempertahankan kualitas pangan yaitu sebagai antimikrobia dan antioksidan. Gingerone dan gingerol berperan dalam menghambat pertumbuhan bakteri E. coli dan B. subtilis, sedangkan kemampuan antioksidannya berasal dari kandungan gingerol dan shogaol yang bertindak sebagai antioksidan primer terhadap radikal lipida [23]. Ma'ruf pun membuktikan bahwa rimpang jahe mempunyai hasil penelitian menunjukkan bahwa bahan aktif jahe (gingerol) mampu menghambat pertumbuhan bakteri [24, 25].

Selain jahe yang berfungsi sebagai antimikroba, kacang-kacangan termasuk kacang hijau mengandung komponen fitokimia yang berfungsi sebagai antimikroba yang dapat menghambat pertumbuhan bakteri penyebab penyakit [26]. Akan tetapi informasi komponen spesifik dari kacang hijau yang bersifat sebagai antibakteri tersebut belum banyak dipublikasikan [17]. Sehingga dalam penelitian ini, jahe merah merupakan komponen utama yang dapat memperpanjang daya simpan produk susu kacang hijau. Selain itu dilakukan juga teknik pemanasan agar mengurangi populasi mikroorganisme atau membunuh mikroorganisme penyebab penyakit dan/atau penyebab kerusakan sehingga produk menjadi lebih awet dan aman. Teknik pemanasan yang digunakan dalam penelitian ini adalah teknik pemanasan pasteurisasi lama atau dikenal dengan low temperature long time yaitu pemanasan dilakukan pada suhu yang tidak begitu tinggi dengan waktu yang relatif lama [27]. Pasteurisasi susu kacang hijau dilakukan dengan suhu $65^{\circ} \mathrm{C}$ selama 30 menit.

Secara umum penelitian ini bertujuan untuk mengetahui pengaruh persentase penambahan sari jahe merah (Zingiber officinale var. Rubrum) terhadap daya simpan susu kacang hijau (Phaseolus radiatus L.). Tujuan khusus penelitian adalah untuk mengidentifikasi daya simpan susu kacang hijau dengan persentase penambahan sari jahe merah yang berbeda dan menganalisis pengaruh persentase penambahan sari jahe merah terhadap daya simpan susu kacang hijau. 


\section{METODE PENELITIAN \\ Rancangan/desain penelitian}

Penelitian ini merupakan jenis penelitian eksperimen, yaitu untuk mengetahui daya terima dan daya simpan susu kacang hijau yang ditambahkan sari jahe merah (Zingiber officinale var. Rubrum) dengan berbagai perlakuan. Desain penelitian adalah true experiment dengan bentuk post-test only control design dengan membandingkan perlakuan pada kelompok eksperimen dan kelompok kontrol.

\section{Sumber data}

Penelitian menggunakan sumber data primer, yaitu hasil uji daya terima susu kacang hijau. Selain itu, diambil pula data daya simpan dari perlakukan penambahan jahe pada susu kacang hijau yang memiliki daya terima yang baik.

\section{Sasaran penelitian (populasi/ sampel/ subjek penelitian)}

Sampel penelitian ini adalah susu kacang hijau yang telah diberi perlakuan penambahan sari jahe merah. Kemudian, beberapa perlakuan yang memiliki daya terima yang baik dilakukan uji daya simpan.

\section{Pengembangan instrument dan teknik pengumpulan data}

Penelitian ini dilakukan dua tahap. Tahap pertama adalah penelitian pendahuluan untuk mengetahui daya terima (organoleptik) yang terbaik dari beberapa variasi sembilan perlakuan penambahan sari jahe merah. Uji daya terima dilakukan pada panelis sebanyak 25 orang panelis agak terlatih dan 5 orang panelis terlatih yaitu mencakup rasa, warna, aroma, dan kekentalan (konsistensi). Setelah penelitian pendahuluan dilakukan dan diperoleh hasil perlakuan terbaik yang disukai panelis, maka penelitian dilanjutkan dengan penelitian utama untuk mengetahui daya simpan susu kacang hijau.

\section{Teknik analisis data}

Data daya terima susu kacang hijau yang diperoleh pada tahap pertama dianalisis secara deskriptif untuk menenentukan perlakuan mana yang memiliki daya terima yang baik. Setelah itu, perlakukan-perlakuan terpilih pada penelitian pendahuluan akan diuji daya simpannya pada penelitian utama. Data yang dihasilkan pada penelitian utama dianalisis secara deskriptif untuk melihat kecenderungan pengaruh penambahan sari jahe merah dengan daya simpan susu kacang hijau yang berbeda.

Tabel 1. Hasil Rerata Skor Uji Organoleptik

\begin{tabular}{lccccccccc}
\hline & P0 & P1 & P2 & P3* & P4 & P5* & P6* & P7 & P8 \\
\hline Warna & 2,43 & 2,37 & 2,30 & 2,40 & 2,17 & 2,43 & 2,43 & 2,37 & 2,57 \\
\hline Aroma & 2,27 & 2,30 & 2,20 & 2,53 & 2,33 & 2,37 & 2,53 & 2,37 & 2,13 \\
\hline Kekentalan & 2,57 & 2,47 & 2,43 & 2,90 & 2,33 & 2,63 & 2,70 & 2,40 & 2,47 \\
\hline Rasa & 2,53 & 2,67 & 2,37 & 2,53 & 2,83 & 2,40 & 2,47 & 2,33 & 2,20 \\
\hline Rerata & $\mathbf{2 , 4 5}$ & $\mathbf{2 , 4 5}$ & $\mathbf{2 , 3 2}$ & $\mathbf{2 , 5 9}$ & $\mathbf{2 , 4 2}$ & $\mathbf{2 , 4 6}$ & $\mathbf{2 , 5 3}$ & $\mathbf{2 , 3 7}$ & $\mathbf{2 , 3 4}$ \\
\hline
\end{tabular}

Keterangan: P3, P5, P6 merupakan perlakuan yang diambil untuk dijadikan perlakuan pada penelitian utama

Tabel 2. Hasil Uji Daya Simpan

\begin{tabular}{ccccc}
\hline $\begin{array}{c}\text { Waktu } \\
\text { Penyimpanan }\end{array}$ & Q0 & Q1 & Q2 & Q3 \\
\hline H0 & 0 & 0 & 0 & 0 \\
\hline H1 & $2,15 \times 10^{2 *}$ & 0 & 0 & 0 \\
\hline H2 & $5,31 \times 10^{3 *}$ & $4,55 \times 10^{3 *}$ & $1,75 \times 10^{3 *}$ & 0 \\
\hline H3 & $7,60 \times 10^{3 *}$ & $4,67 \times 10^{3 *}$ & $3,90 \times 10^{3 *}$ & $2,65 \times 10^{2 *}$ \\
\hline
\end{tabular}

* Keterangan :Jumlah mikroba yang melebihi persyaratan SNI

$\mathrm{Q} 0=$ penambahan jahe $0 \%$

$\mathrm{Q} 1=$ penambahan $\mathrm{jahe} 0,75 \%$

$\mathrm{Q} 2=$ penambahan jahe $1,25 \%$

$\mathrm{Q} 3=$ penambahan jahe $1,5 \%$

$\mathrm{H} 0=$ hari ke- 0

$\mathrm{H} 1=$ hari ke-1

$\mathrm{H} 2=$ hari ke- 2

$\mathrm{H} 3=$ hari ke-3

Paparan hasil analisis yang berkaitan dengan pertanyaan penelitian 


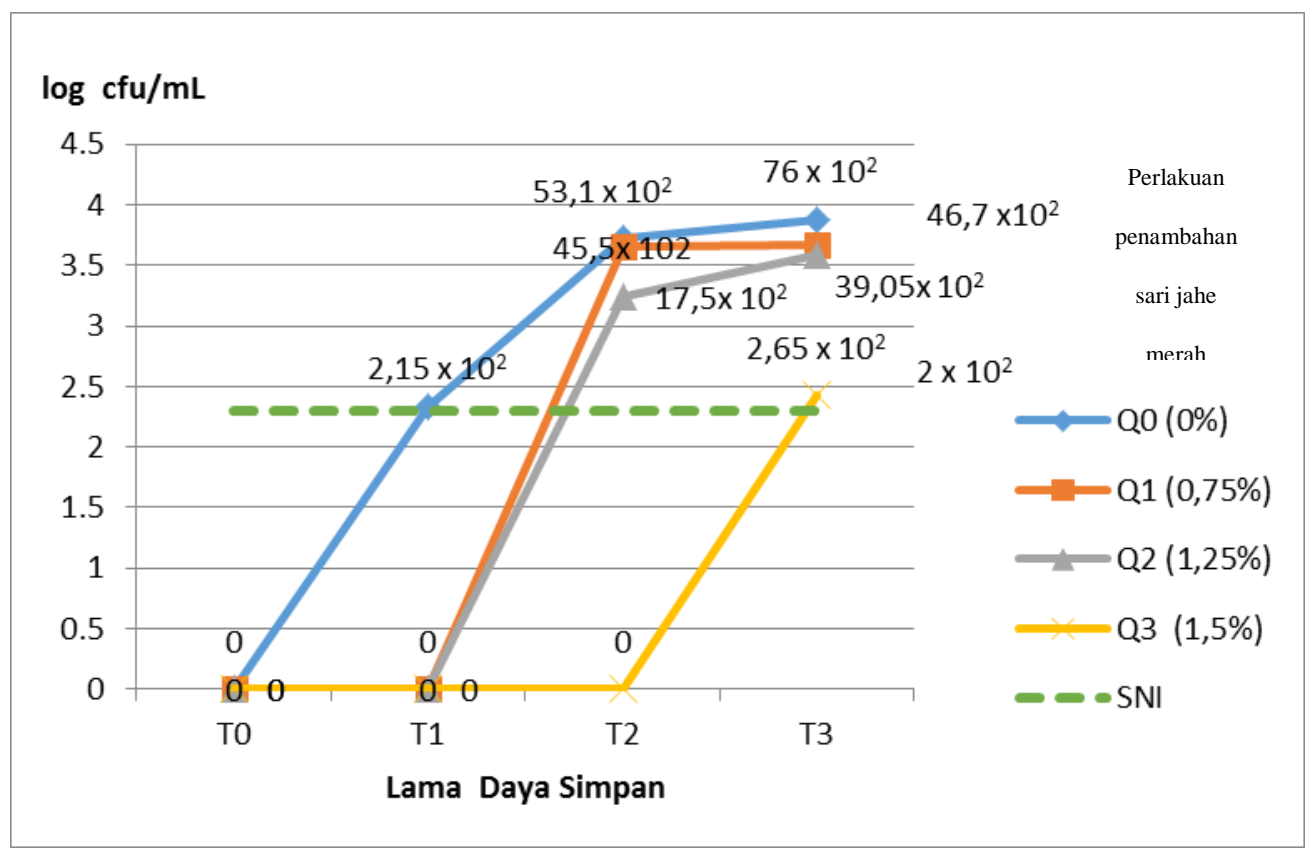

*Keterangan: T0 = hari ke-0; T1 = hari ke-1; T2 = hari ke-2; T3 = hari ke-3

Gambar 1. Hasil Uji Daya Simpan Susu Kacang Hijau dengan Berbagai Perlakuan Penambahan Sari Jahe Merah

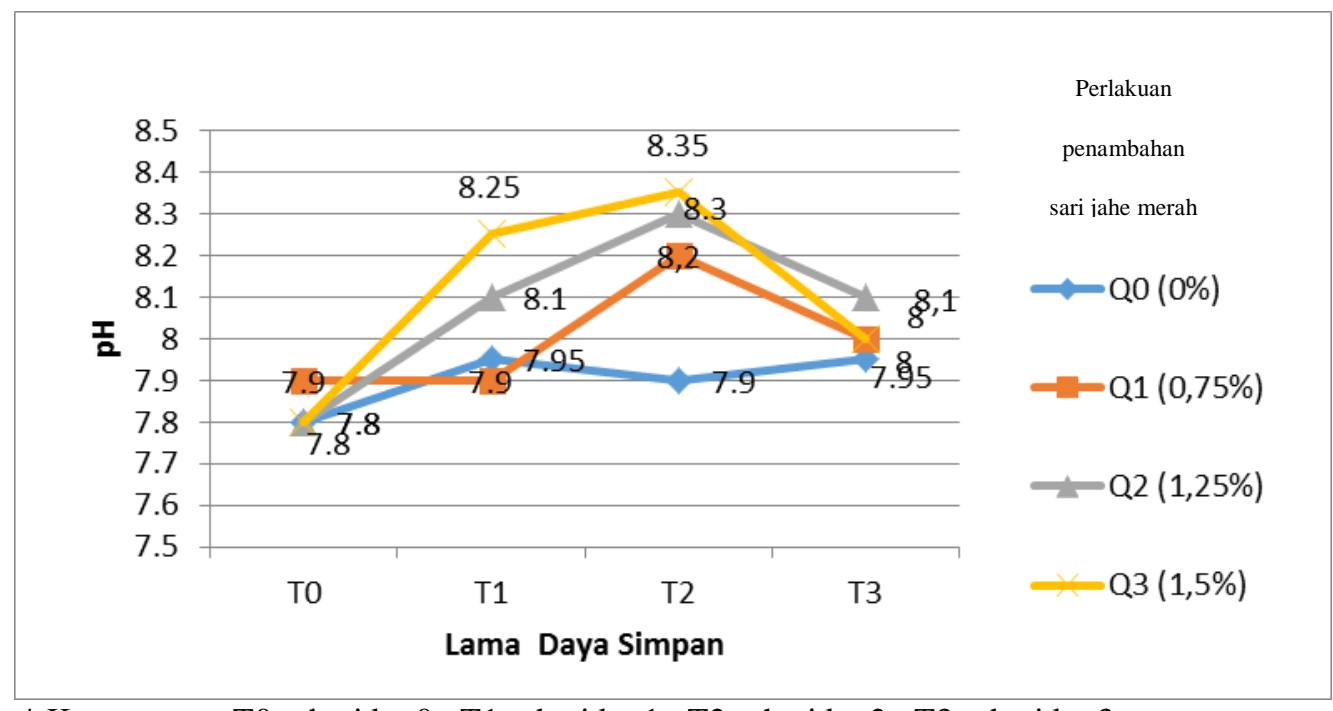

* Keterangan : T0 = hari ke-0 ; T1 = hari ke-1 ; T2 = hari ke-2 ; T3 = hari ke-3

Gambar 2. Grafik pH Susu Kacang Hijau

\section{HASIL PENELITIAN}

\section{Penelitian Pendahuluan}

Penambahan sari jahe merah pada susu kacang hijau dilakukan dengan 9 perlakuan yang berbeda-beda yaitu P0 (perlakuan kontrol) tanpa penambahan sari jahe merah, P1 dengan penambahan sari jahe merah $0,25 \%, 0,5 \%$, $0,75 \%, 1,0 \%, 1,25 \%, 1,5 \%, 1,75 \%$, dan $2,0 \%$. Selanjutnya dilakukan uji daya terima (organoleptik) dengan metode Hedonic Scale Scoring dengan kuesioner sebagai alat ukurnya.
Daya terima meliputi, aroma, warna, rasa, dan kekentalan (konsistensi) dengan panelis sebanyak 30 orang. Rerata skor uji daya terima atau uji organoleptik dapat dilihat pada Tabel 1.

\section{Penelitian Utama}

Setelah penelitian pendahuluan dilakukan dan diperoleh hasil perlakuan terbaik yang disukai panelis, penelitian dilanjutkan dengan penelitian utama untuk mengetahui daya simpan susu kacang hijau. Sebelum dilakukannya uji daya simpan dengan perhitungan 
angka lempeng total (ALT) dengan hitungan cawan metode cawan sebar, susu kacang hijau dengan perlakuan kontrol (Q0) tanpa penambahan jahe, Q1 $(0,75 \%)$, Q2 (1,25\%), dan Q3 (1,5\%) dimasukkan ke dalam botol kecil steril dan kemudian disterilkan menggunakan autoklaf. Selanjutnya susu kacang hijau dengan berbagai perlakuan yang telah disterilkan dapat dilakukan uji daya simpan dengan perhitungan angka lempeng total (ALT) dengan hitungan cawan metode cawan sebar. Hasil uji daya simpan susu kacang hijau dapat dilihat pada Tabel 2.

\section{PEMBAHASAN \\ Penelitian Pendahuluan}

Berdasarkan Tabel 2, hasil rerata skor uji organolpetik, dapat dilihat bahwa rata-rata skor penilaian terhadap warna, aroma, kekentalan, dan rasa menunjukkan skor 2 (agak suka) dan 3 (suka). Hasil uji hedonik tersebut, dipilihlah tiga perlakuan yang memiliki skor rata-rata tertinggi yang banyak disukai panelis yang meliputi warna, aroma, kekentalan, dan rasa yaitu P3 $(0,75 \%)$, P5 (1,25\%), dan P6 (1,5\%) untuk digunakan pada penelitian utama. Karena pada penelitian ini menggunakan desain penelitian true experiment dengan bentuk post-test only control design dengan membandingkan perlakuan pada kelompok eksperimen dan kelompok kontrol, maka P0 (perlakuan kontrol) tanpa penambahan sari jahe merah ditambahkan untuk uji daya simpan pada penelitian utama agar dapat mengetahui dan membandingkan pengaruh persentase penambahan sari jahe merah terhadap daya simpan susu kacang hijau.

\section{Penelitian Utama}

Daya simpan atau umur simpan adalah waktu yang diperlukan oleh produk pangan dalam suatu kondisi penyimpanan untuk sampai pada suatu level atau tingkatan degradasi mutu tertentu [13]. Mutu simpan suatu produk pangan dapat diramalkan dengan mengetahui sifat pertumbuhan mikroba yang menyebabkan kerusakan. Kandungan mikroba pada produk pangan dapat memengaruhi mutu dan menentukan keamanan produk tersebut dikonsumsi. Pertumbuhan mikroba pada produk pangan dipengaruhi oleh faktor intrinsik dan ekstrinsik. Faktor intrinsik mencakup keasaman $(\mathrm{pH})$, aktivitas air (Aw), equilibrium humidity (Eh), kandungan gizi, struktur biologis, dan kandungan antimikroba. Faktor ekstrinsik meliputi suhu penyimpanan, kelembapan relatif serta jenis dan jumlah gas pada lingkungan [13].

Beberapa upaya untuk memperpanjang masa simpan yang dapat dilakukan, yaitu meningkatkan nilai mutu dan memperlambat laju penurunan mutu [13]. Memperpanjang umur simpan produk pangan dapat dilakukan dengan peningkatan mutu awal atau dengan perlakuan selama proses penyimpanan. Untuk memperpanjang umur simpan produk pangan khususnya susu kacang hijau, upaya yang dilakukan adalah menghambat pertumbuhan mikroba dengan perlakuan penambahan senyawa antimikroba pada produk pangan.

Senyawa antimikroba adalah senyawa kimiawi atau biologis yang dapat menghambat pertumbuhan dan aktivitas mikroba. Komponen antimikroba terdapat dalam bahan pangan melalui salah satu dari berbagai cara, yaitu terdapat secara alamiah di dalam bahan pangan, ditambahkan secara sengaja ke dalam makanan dan terbentuk selama pengolahan atau oleh jasad renik yang tumbuh selama fermentasi pangan [12]. Senyawa antimikroba dapat bersifat bakterisidal (membunuh bakteri), bakteristatik (menghambat pertumbuhan mikroba), fungisidal (membunuh kapang), fungistatik (menghambat pertumbuhan kapang), dan germisidal (menghambat germinasi spora bakteri) [21].

Jahe merupakan rempah-rempah yang memiliki komponen bioaktif yang dapat berfungsi sebagai pengawet alami yang tidak toksik dan dapat menghambat pertumbuhan atau membunuh mikroba [20]. Jahe merah yang dikenal sebagai antimikroba digunakan dalam penelitian ini untuk mengetahui pengaruh penambahan sari jahe merah dengan persentase yang berbeda-beda terhadap daya simpan susu kacang hijau.

Untuk mengetahui daya simpan susu kacang hijau yaitu dengan membandingkan persyaratan mutu susu kacang hijau yang mengacu pada persyaratan mutu susu kedelai dengan SNI 01-3830-1995 bahwa persyaratan angka lempeng total (ALT) adalah maksimal $2 \times 10^{2} \mathrm{cfu} / \mathrm{ml}$. Dapat dilihat pada Tabel 3 bahwa Q0 atau perlakuan kontrol tanpa penambahan jahe memiliki umur simpan paling singkat, karena pada hari pertama (H0) sudah menunjukkan jumlah mikroba yang melebihi persyaratan SNI yaitu $2,15 \times$ $10^{2} \mathrm{cfu} / \mathrm{ml}$. Hasil uji daya simpan pada perlakuan Q1 dan Q2 menunjukkan waktu penyimpanan yang sama yaitu hanya bertahan selama 1 hari penyimpanan namun jumlah mikroba kedua perlakuan berbeda. Jumlah mikroba Q1 pada hari kedua penyimpanan (H2) adalah $4,55 \times 10^{3} \mathrm{cfu} / \mathrm{ml}$ sementara pada Q2 adalah $1,75 \times 10^{3} \mathrm{cfu} / \mathrm{ml}$. Perlakuan Q3, perlakuan dengan penambahan sari jahe merah terbanyak memiliki daya simpan yang lebih lama dibandingkan perlakuan lainnya yaitu selama 2 hari penyimpanan. Hari ketiga penyimpanan (H3) pada perlakuan Q3 jumlah mikroba yang dihasilkan adalah $2,65 \times 10^{2}$ $\mathrm{cfu} / \mathrm{ml}$. Hal ini membuktikan bahwa, jahe memiliki senyawa antimikroba yang dapat bersifat bakterisidal (membunuh bakteri) dan bakteristatik (menghambat pertumbuhan mikroba) karena semakin banyak 
penambahan sari jahe pada perlakuan semakin lama umur simpan perlakuan tersebut.

Masa penyimpanan maksimal susu kacang hijau yaitu selama 3 hari dengan perlakuan penambahan sari jahe merah sebanyak $1,5 \%$ atau pada perlakuan Q3. Grafik banyaknya jumlah mikroba pada setiap perlakuan dapat dilihat pada Gambar 1 .

Berdasarkan Gambar 1, dapat diketahui bahwa rerata umur simpan susu kacang hijau hanya bertahan selama satu hari penyimpanan. Perlakuan kontrol Q0 $(0 \%)$ atau tanpa penambahan sari jahe merah hanya memiliki waktu simpan selama 0 hari. Hal ini dikarenakan pada perlakuan Q0 yaitu susu kacang hijau tanpa penambahan sari jahe tidak memiliki senyawa antimikroba. Menurut Ma'ruf, jahe terbukti mempunyai aktivitas sebagai antimikroba [24]. Senyawa fenol pada jahe dapat mengkoagulasi protein bakteri sehingga bakteri akan mengalami kematian. Senyawa fenol merupakan salah satu kelompok utama bahan antimikroba kimiawi [28]. Hasil penelitian lain pun menunjukkan bahwa bahan aktif jahe (gingerol) mampu menghambat pertumbuhan bakteri [25]. Hal ini dibuktikan pada Q1 dengan penambahan sari jahe merah yaitu sebanyak $0,75 \%$ memiliki umur simpan yang lebih lama dibandingkan perlakuan tanpa penambahan sari jahe merah atau perlakuan kontrol (Q0).

Perlakuan Q2 dengan penambahan sari jahe merah sebanyak $1,25 \%$ memiliki umur simpan yang sama seperti pada Q1, tetapi jumlah mikroba pada Q2 lebih sedikit dibandingkan Q1. Perlakuan Q3 yang memiliki penambahan sari jahe merah sebanyak $1,5 \%$, memiliki daya simpan lebih lama dari perlakuan lainnya yaitu selama 2 hari. Hal ini dikarenakan kemampuan suatu zat antimikroba dalam menghambat pertumbuhan mikroba dapat dipengaruhi oleh beberapa faktor, misalnya konsentrasi zat pengawet, waktu penyimpanan, suhu lingkungan, sifat-sifat mikroba (jenis, konsentrasi, umur, dan keadaan mikroba), sifatsifat fisik dan kimia makanan, termasuk kadar air, $\mathrm{pH}$ serta jenis dan jumlah senyawa di dalamnya [12], sehingga meskipun dengan perlakuan penambahan sari jahe berbeda dan jumlah mikroba yang tumbuh berbeda namun pada perlakuan Q1 dan Q2 memiliki daya simpan yang sama. Adapun faktor-faktor memengaruhi kemampuan zat antimikroba jahe merah yang ada pada susu kacang hijau adalah konsentrasi zat pengawet (konsentrasi sari jahe merah), sifat-sifat mikroba (jenis, konsentrasi, umur, dan keadaan mikroba), sifat-sifat fisik dan kimia makanan, kadar air, $\mathrm{pH}$ serta jenis dan jumlah senyawa di dalamnya [12].

Derajat keasaman $(\mathrm{pH})$ merupakan salah satu faktor lingkungan yang memengaruhi pertumbuhan dan aktivitas mikroorganisme [12]. Penelitian ini dilakukan uji $\mathrm{pH}$ sebagai data pendukung untuk melihat keterkaitan antara $\mathrm{pH}$ dan daya simpan susu kacang hijau. Berikut adalah hasil uji $\mathrm{pH}$ yang disajikan pada Gambar 2.

Rerata $\mathrm{pH}$ susu kacang hijau dengan perlakuan kontrol dan perlakuan penambahan sari jahe merah memiliki pH di atas 7 atau bersifat basa. Dapat dilihat bahwa Q3 memiliki rata-rata $\mathrm{pH}$ tertinggi dibandingkan perlakuan lainnya dan sebaliknya Q0 memiliki $\mathrm{pH}$ terendah. Berdasarkan Gambar 2 dapat disimpulkan bahwa semakin tinggi perlakuan penambahan sari jahe merah, maka semakin tinggi $\mathrm{pH}$ pada perlakuan tersebut. Hal ini dikarenakan susu kacang hijau memiliki sifat basa dengan $\mathrm{pH}$ lebih dari 7, sedangkan sari jahe merah memiliki $\mathrm{pH}$ 6,9. $\mathrm{pH}$ menjadi basa dikarenakan aktivitas mikroba tahan basa yang meningkat.

Umumnya mikroba menyukai $\mathrm{pH}$ netral yaitu $\mathrm{pH}$ 7. Beberapa bakteri dapat hidup pada $\mathrm{pH}$ tinggi (medium alkali). Apabila mikroba ditanam pada media dengan $\mathrm{pH} 5$ maka pertumbuhan didominasi oleh jamur, tetapi apabila $\mathrm{pH}$ media 8 maka pertumbuhan didominasi oleh bakteri. Berdasarkan pH-nya, mikroba dapat dikelompokan menjadi 3 yaitu mikroba asidofil adalah kelompok mikroba yang dapat hidup tumbuh baik pada $\mathrm{pH} 6,0-8,0$, mikroba mesofil (neutrofil) adalah kelompok mikroba yang dapat hidup pada $\mathrm{pH} 5,5-8,0$, dan mikroba alkafil adalah kelompok mikroba yang dapat hidup pada $\mathrm{pH}$ 8,4-9,5 [29]. Dapat dikatakan bahwa mikroba yang tumbuh pada penelitian ini adalah jenis mikroorganime mesofilik (neutrofilik), yaitu jasad yang dapat tumbuh pada $\mathrm{pH}$ antara 5,5-8,0.

Berdasarkan hasil penelitian, dapat dinyatakan bahwa ada kecenderungan pengaruh persentase penambahan sari jahe merah yang berbeda terhadap daya simpan susu kacang hijau. Hal ini terjadi karena semakin banyak penambahan jahe maka semakin sedikit jumlah mikroba yang akan tumbuh dan semakin lama daya simpan susu kacang hijau.

\section{KESIMPULAN}

Perlakuan kontrol (Q0) atau tanpa penambahan sari jahe merah hanya memiliki daya simpan selama 0 hari, perlakuan Q1 dengan penambahan sari jahe merah sebanyak $0,75 \%$ dan Q2 sebanyak $1,25 \%$ memiliki daya simpan yang sama yaitu selama 1 hari. Sementara perlakuan Q3 dengan penambahan sari jahe merah sebanyak $1,5 \%$ memiliki daya simpan selama 2 hari. Terdapat kecenderungan adanya pengaruh persentase penambahan sari jahe merah terhadap daya simpan susu kacang hijau. Semakin banyak persentase penambahan sari jahe merah, maka semakin lama daya simpan susu kacang hijau. 


\section{UCAPAN TERIMA KASIH}

Ucapan terimakasih kepada Ketua Jurusan Gizi Politeknik Kesehatan Kemenkes Banjarmasin beserta Ketua Sub Unit Laboratorium Jurusan Gizi atas izin penggunaan Laboratorium Ilmu dan Teknologi Pangan serta Laboratorium Mikrobiologi Pangan dalam proses penelitian ini.

\section{DAFTAR RUJUKAN}

1. Astawan M. Sehat dengan Hidangan Kacang dan Biji-bijian. Jakarta: Penebar Swadaya; 2009.

2. Pusdatin. Booklet Kacang Hijau. Kementrian Pertanian RI Direktorat Tanaman Pangan. [Online]. Jakarta: Departemen Pertanian; 2012 (Diunduh tanggal 24 Desember 2013). Available

from:

http://pusdatin.setjen.deptan.go.id)

3. BPS. Luas Panen- Produktivitas- Produksi Tanaman Kacang Hijau Seluruh Provinsi. [Online]. Jakarta: Badan Pusat Statistik; 2013 (Diunduh tanggal 19 Desember 2013). Available from: www.bps.go.id.

4. Khomsan A. Solusi Makanan Sehat. Jakarta: PT. Raja Grafindo Persada; 2006.

5. Rehman R, Akram M, Akhtar N, Jabeen Q, Saeed T, Shah SMA, Ahmed K, Shaheen G, dan Asif HM. Zingiber officinale Roscoe (pharmacological activity). Journal of Medicinal Plants Research. 2011; 5: 344-348

6. Pramitasari D. Penambahan Ekstrak Jahe (Zingiber officinale Rosc.) dalam Pembuatan Susu Kedelai Bubuk Instan dengan Metode Spray Drying: Komposisi Kimia, Sifat Sensoris, dan Aktivitas Antioksidan [Skripsi]. Surakarta: Fakultas Pertanian Universitas Sebelas Maret Surakarta; 2010

7. Nurcahyo. Kayu Manis, Jahe Berpotensi Antioksidan. [Online]. 2009 (Diunduh tanggal 27 Januari 2014). Available from: www.indonesiaindonesia.com.

8. Ernawati. Pemanfaatan Sari Rimpang Jahe (Zingiber officinale) sebagai Antibakterial Alami pada Susu Pasteurisasi Berdasarkan Penurunan Jumlah Bakteri Escherichia coli. Artikel Ilmiah. Surabaya: Fakultas Kedokteran Hewan Universitas Airlangga; 2010.

9. Fathona D. Kandungan gingerol dan shogaol, intensitas kepedasan dan penerimaan panelis terhadap oleoresin jahe gajah (Zingiber officinale var. Roscoe), Jahe Emprit (Zingiber officinale var. Amarum), dan Jahe Merah (Zingiber officinale var. Rubrum) [Skripsi]. Bogor: Institut Pertanian Bogor; 2011.
10. Rukmana R. Temu-temuan (Apotik Hidup di Pekarangan). Yogyakarta: Kanisius; 2004.

11. Ali BH, Blunden G, Tanira MO, dan Nemmar A. Some Phytochemical, Pharmacological and Toxicological Properties of Ginger (Zingiber officinale Roscoe): A review of recent research. Food and Chemical Toxicology. 2008; 46 : 409-420.

12. Wang WH dan Wang ZM. Studies of commonly used traditional medicine-ginger. Zhongguo Zhong Yao Za Zhi. 2005;30:15691573.

13. Tapsell LC, Hemphill I, Cobiac L, Patch CS, Sullivan DR, Fenech M, Roodenrys S, Keogh JB, Clifton PM, Williams PG, Fazio FA, dan Inge KE. Health benefits of herbs and spices: the past, the present, the future. Med. J. Aust. 2006; 185 (Suppl. 4),S4-S24.

14. Rahingtyas DK. Pemanfaatan Jahe (Zingiber officinale) sebagai Tablet Isap untuk Ibu Hamil Dengan Gejala Mual dan Muntah [Skripsi]. Bogor : Fakultas Pertanian, Institut Pertanian Bogor; 2008.

15. Lentera T. Khasiat dan Manfaat Jahe Merah: Si Rimpang Ajaib. Jakarta: Agro Media Pustaka; 2012.

16. Widowati S dan Misgiyarta. Efektifitas Bakteri Asam Laktat (BAL) dalam Pembuatan Produk Fermentasi Berbasis Protein/Susu Nabati. Prosiding Seminar Hasil Penelitian Rintisan dan Bioteknologi Tanaman. Jakarta: Balai Penelitian Bioteknologi dan Sumberdaya Genetik Pertanian; 2007. 360 - 373.

17. Wijaningsih, W. 2008. Aktivitas Antibakteri In Vitro dan Sifat Kimia Kefir Susu Kacang Hijau (Vigna radiata) oleh Pengaruh Jumlah Starter dan Lama Fermentasi. Semarang: Program Pasca Sarjana Universitas Diponegoro Semarang.

18. Supriyono T. Kandungan Beta Karoten, Polifenol Total dan Aktivitas "Merantas" Radikal Bebas Kefir Susu Kacang Hijau (Vigna radiata) oleh Pengaruh Jumlah Starter (Lactobacillus bulgaricus dan Candida kefir), dan Konsentrasi Glukosa [Tesis]. Semarang: Program Pascasarjana Unversitas Diponegoro Semarang; 2008.

19. Badan Standardisasi Nasional SNI No. 013830-1995, Syarat Mutu Susu Kedelai. Jakarta: Badan Standardisasi Nasional; 1995.

20. Theresia A. Optimalisasi Penambahan Jahe (Zingiber officinale Rosc.) pada Sponge Cake: Ditinjau secara Mikrobiologi dan Sensoris [Skripsi]. Semarang: Fakultas Teknologi Pertanian Universitas Katolik Soegijapranata; 2006. 
21. Jawetz E, Melnick JL, dan Adelberg EA. Mikrobiologi Kedokteran. Surabaya: Salemba; 2008.

22. Mathur JN. Ginger: Its Role In Xenobiotic Metabolism. New Delhi: ICMR Offset Press; 2003.

23. Fakhrudin MI. Kajian Karakteristik Olereosin Jahe Berdasarkan Ukuran dan Lama Perendaman Serbuk Jahe dalam Etanol [Skripsi]. Surakarta: Fakultas Pertanian Universitas Sebelas Maret Surakarta; 2008.

24. Ma'ruf. Bioaktifitas Ekstrak Jahe. [Online]. 2011. Available from: biologi-fkip.unri.ac.id.

25. Wiryawan KG, Suharti S, dan Bintang $M$. Kajian Antibakteri Temulawak, Jahe, dan Bawang Putih terhadap Salmonella lyphimuriam serta Pengaruh Bawang Putih terhadap Performan dan Respon Imun Ayam Pedaging. Media Peternakan. 2005; 2(28): 5262.

26. Arnelia. Fitokimia Komponen Ajaib, PJK, DM dan Kanker. [Online]. 2004 (Diunduh 12 Januari 2014). Available from: kimia.net.lipi.go.id.

27. Effendi, MS. Teknologi Pengolahan dan Pengawetan Pangan. Bandung: Penerbit Alfabeta; 2009.

28. Pelczar MJ dan Chan ECS. Dasar-Dasar Mikrobiologi. Jakarta: UI Press; 2005.

29. Brooks G, Butel J, Morse S. Mikrobiologi Kedokteran Edisi 2. Jakarta: Penerbit buku Kedokteran EGC; 1994. 